\title{
LEGAL WRITING
}

\section{D Campbell*}

It is easier to criticise a work of art than to produce one, and much more simple to describe the characteristics of good legal writing than to make an enduring contribution to the literature of the law. Nevertheless this is an occasion on which it is appropriate to set out some of the qualities of good legal work. This is the third issue of a publication in which law students of this College will be developing their skill in written legal analysis and argument. It is an opportunity for considering the standards by which a writer should be guided both in his own creative work and in assessing the work of others.

Probably no quality is more essential than enthusiasm. Writing that is outstanding nearly always possesses dynamic vitality. It reflects the author's feeling that what he wishes to say must be said, that he writes not for the sake of writing but because his convictions impel him to do so. There are a dozen other characteristics of good writing which, like enthusiasm, are the marks of good writing in general. This article, however, makes no attempt to elaborate these qualities. It is concerned with more mundane aspects of the art of composition, being devoted to a discussion of some considerations which should especially be kept in mind by legal writers.

Instead of illustrating the pitfalls to be avoided by giving hypothetical examples, or by selecting specimens from past performances of students, I shall take passages from Law and Social Change in Contemporary Britain ${ }^{1}$ by Professor W Friedmann, LLD (London, Dr jur (Berlin), LLM (Melbourne), Professor of Law at the University of Toronto. If faults can be found in the work of a scholar of world fame, such as Professor Friedmann, the law student venturing into this field need not be alarmed to discover that his own first efforts possibly fall short of perfection.

* Professor of Law, Victoria University of Wellington. The paper was first published at (1955) 1 VUWLR Part 3, 7 .

1 The book was published in 1951, and is a collection of essays that had previously appeared in legal periodicals. This partly explains the inadequate treatment of several House of Lords decisions. The above article was written in 1952. It was, in fact, the first article to be written for this Review. For various reasons its publication has been long delayed, but I have taken the liberty of publishing the article as originally written. 


\section{FACE FACTS}

Legal exposition is indistinguishable from the work of a physical scientist in this: it demands absolute integrity. To disregard inconvenient facts is to destroy utterly and completely the value of the work produced. In law, as in science, the available data increase day by day, and a hypothesis tenable last year may not be tenable now. It is of fundamental importance for a writer to develop from the outset a determination to be ruthless with any of his work - no matter what labour it entailed, nor what charm and symmetry it may possess if facts come to light which cannot be reconciled with the views previously formed.

An elementary example may be found when a decision of the House of Lords runs counter to a trend which could be discerned in earlier cases. As the House has no power to overrule its own decisions, its exposition of the law is conclusive until legislation alters the law. A theory which cannot accommodate a recent House of Lords decision must, therefore, inevitably be abandoned. It is as if an ornithologist, after declaring that all swans were white, discovered a black swan.

Consider, however, Professor Friedmann's treatment of this problem.

1 In 1928 Lord Sumner in the House of Lords expressed the view that if a taxpayer could arrange his affairs in such a way that he was outside the scope of a taxing statute, it was legitimate for him to do so. He even declared (though it went beyond his judicial function to pronounce on the question of ethics) that strictly speaking the taxpayer incurs no moral censure in avoiding tax in this way. The unsocial behaviour of those who, aided by the ingenuity of their lawyers, contrive to throw the burden of taxation on to others, naturally incurs a good deal of moral censure, notwithstanding Lord Sumner's opinion to the contrary, and Friedmann endeavours to show that in more recent cases the earlier view has been abandoned. He adds in a footnote: "But for an even more recent return to the former approach, see Vestey's (Lord) Executors $v$ Inland Revenue Commissioners [1949] 1 All ER 1108". If the House of Lords in 1949 shares the view of the House of Lords in 1929, can it still be maintained that the judicial approach to taxation statutes has in the meantime undergone a profound change?

2 Friedmann detects in recent cases a doctrine which has the effect of diminishing the value of contract as a measure of security against economic risks. In support he cites British Movietonews $v$ London District Cinemas Ltd [1950] 2 All ER 390, in the Court of Appeal, and quotes from the judgment of Lord Justice Denning. A footnote, however, informs us that the House of Lords has now reversed the decision and repudiated the wider significance attached to the doctrine by the Court of Appeal, especially in the judgment of Lord Justice Denning. The text nevertheless remains unaltered. (The only possible excuse for this is that the House of Lords decision may have been reported too late for the text to be rewritten.) It 
is delicious to read that the new "development" discussed in the text is one "for which none of the current theories of contract can adequately account".

3 Should the rule in Donoghue $v$ Stevenson [1932] AC 526, be widened into a general rule of care? Friedmann seems to think that it should. Among the cases he cites is the decision of the Court of Appeal in Horton v London Graving Dock Co [1950] 1 KB 421, in which the majority of the judges based the wider interpretation of the duties of an occupier towards an invitee on the principle of Donoghue $v$ Stevenson. Again there is a footnote, with the information that this view was repudiated by a majority decision of the House of Lords, which reversed the Court of Appeal.

4 The state of the law in regard to liability for dangerous premises has been very effectively attached by Friedmann and other writers for some years. The classification into the categories of persons entering as of right, contractees, invitees, licensees and trespassers has earned well-merited criticism. But in the book now under consideration Friedmann purports to set out "Recent Trends in the Law of Torts" ie statutory and judicial development of the law; and liability for dangerous premises is given as an instance in which there has been recent judicial development. "The general trend of the decisions", he says, "adumbrates a general duty of care towards visitors other than trespassers". This suggests that Friedmann's earlier writings have borne fruit, and that we are moving away from the former rules and classifications. We should not, however, overlook the footnotes, especially footnote 6a: "But see now, for an unconvincing revival of old distinctions by the House of Lords, London Graving Dock Co $v$ Horton [1951] 2 All ER 1". The revival may be unconvincing, but what becomes of the "general trend of the decisions"?

\section{NO HALF-TRUTHS}

Next to integrity, is there any more desirable quality than candour? Legal writing necessarily involves condensation, selection, extracting statements from their context, emphasis on particular aspects of a case. One may innocently and frequently err in this process, and, indeed, there is scope for many differing opinions as to what is crucial and what is not. But a writer does less than justice to his readers, and nothing to enhance his own reputation, if he does not constantly strive to state or summarise objectively and impartially all the material that distinctly bears on the point at issue. Above all, when he is attacking a decision he is under the clearest obligation to suppress nothing that makes the decision supportable.

Consider by way of illustration, Friedmann's commentary on $R \quad v$ Electricity Commissioners [1924] $1 \mathrm{~KB} 171$. With ample justification he criticises this decision. In fact, he displays it on no fewer than five separate occasions as a sorry example of the "abuse" of prerogative jurisdiction over quasi-judicial administrative action. But in two important respects his treatment leaves much to be desired, as we are told but half of what should be 
told. First of all, in his summary of the principle of the decision (page 30) he says that the scheme in question was held to be quasi-judicial "because such a scheme affected private rights". If this were a correct statement of the ratio decidendi the decision would be worthy of all the epithets which he applied to it. But he has told us of only one of the two conditions which the Court of Appeal stated to be necessary to make a tribunal quasijudicial. The other condition was that the tribunal must have the duty to act judicially. In $R$ $v$ Legislative Committee of the Church Assembly [1928] 1 KB 411, 415, Lord Hewart CJ said:

In order that a body may satisfy the test it is not enough that it should have legal authority to determine questions affecting the rights of subjects; there must be super-added to that characteristic the further characteristic that the body has the duty to act judicially. The duty to act judicially is an ingredient which, if the test is to be satisfied must be present.

(When inveighing against the decision after a further 140 pages, the author does set out both these essentials.)

But there is a further unsatisfactory feature of Friedmann's discussion of this case. He maintains over and over again that since this decision in 1924 there has been a "judicial revolution" in the attitude of the courts on this question. But he does not have the candour to admit that the principle enunciated by $R v$ Electricity Commissioners in 1924 was expressly quoted and followed by the Privy Council in Nakkuda Ali v M F de S Jayaratne [1951] AC 66 which he cites at page 170. His view (expressed at the foot of page 247) is that recent cases, including this one, show a "sharp reversal" of the attitude adopted in 1924. The reader is left to infer that the test propounded by the Court of Appeal in 1924 has now been abandoned. Certainly one would never suspect, from Friedmann's discussion, that the decision in 1951 purported to follow and apply the very principle enunciated in 1924.

Just as a court can have no confidence in counsel who do not frankly deal with the difficulties which their submissions involve, so a reader's faith in an author is apt to be shaken if his arguments are found to be based on incomplete or misleading statements of the relevant materials.

\section{NO STRAW-MEN}

This part of my article might equally well be headed "No distortion".

One who is developing an argument which involves rejecting the decision of a court in a previous case may (consciously or unconsciously) read into the decision something which cannot fairly be found in it but which provides a very good target for attack. Similarly, opinions and motives may without sufficient justification be attributed to the courts and then made the subject of criticism or adulation, as personal predilection may require. This is a subtle danger, to which inexperienced writers who have not been educated by criticism (and very junior counsel) are particularly exposed. The remedy, other than that afforded by 
painful experience, lies in self-criticism. A writer must impose on himself considerable restraint. Before some view is attributed to a court - especially when this view is about to be condemned - he must first examine the decision sufficiently closely and sympathetically to be reasonably certain that he draws the correct conclusion. Unless he feels this degree of assurance the limit of what is permissible is to make a hypothetical submission: if the decision implies [that the right of private property is to be valued more highly than the public interest] it ought not to be followed.

I shall attempt to illustrate these maxims by citations from Friedmann. Obviously my inability to accept the inference he draws from various decisions may result from a lack of perception on my part. In regard to the examples given under this heading it is to be understood that they are offered without any dogmatic assurance that my own conclusions are the correct ones.

Friedmann is very critical of the decision of the House of Lords in Kent $v$ East Suffolk Catchment Board [1941] AC 74. After dealing with this case he refers to the decision of the Court of Appeal in Smith $v$ River Douglas Catchment Board [1949] 2 KB 500. Here, he says, the Court of Appeal was "obviously unsympathetic to the principle of Kent's case". Examination of the judgments of the Court of Appeal shows, in my opinion, that this unsympathetic attitude is pure invention, inspired by the desire to prop up the criticism of the earlier decision.

In Nakkuda Ali $v$ MF de S Jayaratne [1951] AC 66, the Privy Council, he tells us, "expressed its disagreement with Liversidge $v$ Anderson [1942] AC 206 (HL) in unmistakable terms". I think that one who reads the Privy Council's advice in this case will look in vain for evidence of disagreement, let alone for its expression in unmistakable terms. It may be pertinent to add that Friedmann's view of Liversidge $v$ Anderson appears to be that it comes "dangerously close to a legitimation of administrative absolutism".

In $R v$ Paddington Rent Tribunal [1949] 1 KB 666, the Paddington Borough Council referred to a rent tribunal for review several hundred tenancies in a very large block of flats. This action was taken under a statute relating to furnished premises. In the great majority of these cases the tenant was not consulted, and was perfectly satisfied with the conditions of his tenancy. So little care was taken by the Borough Council that it alleged that all the flats were let furnished, though in fact the great majority were not. Some of the flats included among the applications were not even occupied by tenants. No attempt was made by the Council to ascertain whether there was any ground for referring the individual cases to the tribunal. It was held that the proceedings were out of order, and that the tribunal existed to deal with individual cases where hardship existed or might reasonably be supposed to exist. But Friedmann says: "The decision depends on the respective value attributed to the right of the landlord to use his property on his own terms, and the rights of 
the State to ensure some fairness between the parties, at a time of general housing shortage". This, in my opinion, is as grotesque a distortion of the decision as can be conceived.

In Morgan $v$ Liverpool Corporation [1927] 2 KB 131, it had to be determined whether a broken sash-cord in a window constituted a breach of a statutory warranty by a landlord that a house be kept "in all respects reasonably fit for human habitation". One of the majority of the judges in the Court of Appeal said:

I should be sorry in any way to cut down the responsibility which is thrown upon landlords by this term in favour of those who occupy houses of this class. It is important, however, that one should deal reasonably with the interpretation, and not overlook that word ["reasonably"] which is found in this portion of the sub-section. It appears to me that the breaking of a window cord is an accident which may take place in any sort of house. Although in order to make a house in all respects fit for habitation I should think it is clear that it must have windows, and windows that open, it appears to me that the breaking of a window cord is an incident in the course of habitation of a house which must from time to time occur in all classes and kinds of houses inhabitated by all kinds and classes of persons, and in itself I cannot see that the incident afforded a proof or a test that one could apply in determining whether or not the house was fit or unfit for human habitation.

A different view has commended itself to judges in later cases, but by what manner of interpretation can it be maintained (in Friedmann's words) that the judge who expressed himself in those terms was "obstinately frustrating the clear objective of the statute"? Does such a judgment warrant being described as a "somewhat cynical interpretation of what sort of house is fit for the underdog to live in"?

\section{BE CONSISTENT}

Though the life of the law, as Holmes said, is not logic but experience, he did not, I think, exhort us to be illogical. If we urge the legislature or the courts to adopt some view we should not in the next breath plead with them to reject it. In a work ranging over the whole field of law the advice "be consistent" may no doubt be a counsel of perfection, but in the less ambitious essays that may grace these pages it should not be beyond attainment.

A good writer will not only avoid inconsistency. If he makes statements which are apparently inconsistent, though not really so, he will not leave the reader to grope for the solution. I do not deny the virtue of paradox; but unless he is capable of emulating Bernard Shaw he should run the risk of being termed prosaic and have as his ideal the persuasive, forceful, but inexorably logical presentation of his case.

Take the question of liability without fault, and Friedmann's discussion of the problem. Should a defendant be liable in tort in the absence of wilful, reckless or negligent wrongdoing? In a section headed "The Return to Judicial Conservatism" Read v Lyons \& Co 
[1947] AC 156 is cited. This was a case in which it was held that the defendant was not liable without proof of fault. Professor Friedmann quotes this case as an outstanding example of "a return to a more conservative, historical and casuistic approach to precedent". But after another six pages the author is himself stressing the value of a system of law which couples tort liability with standards of conduct (ie which rejects liability without fault). He says: "It is clearly in the public interest, and in particular in the interest of workmen operating machines, to have liability dependent on the maintenance of certain standards of conduct".

Consider next Friedmann's discussion of Smith $v$ River Douglas Catchment Board (cited above). In this case the Board had entered into an agreement with a number of landowners. They undertook to pay certain contributions and the Board undertook to erect and maintain certain flood banks. The Board's undertaking was expressed in an agreement executed under the seal of the Catchment Board and signed by the landowners. The work was negligently performed. Friedmann expresses pained surprise that the Court of Appeal unanimously held the Board liable for breach of contract. The Court, he says, "gave no consideration at all to the public law question involved". Yet later he says: "Where [a Catchment Board] has entered into an agreement which can fairly be interpreted as a contract, it should be held liable accordingly". And if this is the test, how can it also be maintained that "the relative prevalance of public policy or private interests must decide whether a transaction involving a public authority is a private law contract"?

Friedmann's statement that taxation is a cheap means by which the State finances its costly social service schemes may perhaps get by under the guise of a brilliant paradox.

When nearly the whole of a book is devoted to the thesis that judicial attitudes need to be adapted to current social realities, is there not an apparent inconsistency when the author concedes: "It would be idle to expect, even if it were desirable, that the courts could be the main instrument in adjusting law to new economic and social conditions"? Does this concede that attempts by judges to act in this way are undesirable.

If, as he says, a glance at any modern law report shows that "an increasing and, in many cases, an overwhelming proportion of decided cases is concerned with statute law", is it credible that "the steadily growing predominance of statute law in the life of modern communities is still insufficiently appreciated in the judicial approach to statute law"?

\section{BE CLEAR AND ACCURATE}

1 Statutory and case references should be correct. So long as authors, typistes, printers and proof-readers are not infallible, slips are unavoidable; but painstaking care and ample checking can do a great deal to keep errors to a minimum In Friedmann's book I noticed only three incorrect case references (on pages 31, 158 and 176). 
2 Where certainty is possible, facts and principles must be stated with complete accuracy. To take half a dozen examples from Friedmann: it is not true that before the First World War physical or legal impossibility was the only means by which a contract could be discharged, apart from breach (page 67). It was not the rule, before Donoghue v Stevenson, that contractual liability of A to B excluded tort liability of A to C (page 75). The concept of "gross negligence" is not alien to English law (page 91); the majority of the House of Laws in London Graving Dock $v$ Horton did not repudiate any general duty of care on the part of an invitor (page 96). Salmond did not define law as rules laid down by the law courts (page 238). The presumption in favour of mens rea as a condition of criminal liability is not the most important aspect of - nor in any way derived from - the rule that penal laws should be construed strictly in favour of the subject (page 261).

3 The technical language of the law should be employed with precision. It is inappropriate to speak of "exercising an immunity", or to cite "the Court of Appeals" (in England), or to say that in reaching its decision "the court had to prove" certain facts.

4 Clarity of expression stems in the main from clarity of thought; but even when a writer's ideas are clear he has to strive to use words that convey his ideas with equal clarity. Friedmann gives us one charming oddity ("the first ten amendments of the Constitution, in particular the First, the Fifth, and the Fourteenth Amendments"), but on the whole he has an extremely clear and lucid style. I suppose, however, that he does not mean what he says when he asserts: "There is no reason to doubt that the administrator is less capable of exercising discretion than other sections of the community"; and there is avoidable obscurity in the statement: "The presumption [of mens rea] is still justified in the case of common law crimes, whether consolidated by statute or not, but it should be discarded in the case of modern statutory offences unless they clearly require mens rea and are, at bottom, public law remedies, sanctions for the enforcement of administrative law".

It would be a flagrant injustice to the author of Law and Social Change in Contemporary Britain were I not to add that the book teems with vital and stimulating ideas and deals with legal problems of profound importance. It is my believe that the greater the significance of a book, the more does it justify a close and critical scrutiny. Students who read this book will find it extremely illuminating. But to profit to the full from any legal work it must be read critically. In like fashion the student who applies himself to the task of legal writing should aim at satisfying the exacting standards that a work of legal scholarship demands.

A long step in the right direction has been taken when a student comes to appreciate the full meaning of Ibsen's aphorism: "To write is to go to law with oneself". 